\title{
Una visión de la mujer española en la prensa anglosajona del XIX
}

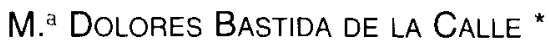

\begin{abstract}
RESUMEN
ABSTRACT

La larga tradición anglosajona de The old English tradition of travel chronicles, together with press and communication advances, gave rise to cronicas de viaje, junto a los avances en prensa y comunicaciones, propiciaron la aparición de una cierta imagen de la mujer española en publicaciones gráficas de la segunda mitad del siglo xIX. La nostalgia romántica de los artistas del xIx por una España rica en huellas del pasado resultó en una visión de la española cargada de pintoresquismo y crítica a su retraso social. Los tópicos de esa visión se escenificaron en la prensa ilustrada siguiendo variantes estéticas de la época: la variante positivista de la viñeta tipológica; la literario-costumbrista de los relatos y guias de viaje; la periodística a particular image of Spanish women in British and American magazines of the second half of the nineteenth century. The artist's Romantic longing for the legacy of Old Spain resulted in both a picturesque view of her women and criticism of their backward social condition. The graphic press set down a variety of images of Spanish women following aesthetic trends of the times: the positivist approach in typological vignettes; high-art images from touristic literature; a journalist's view in news illustrations.
\end{abstract}

del dibujo de noticia.

El entusiasmo por el saber y la explosión educativa del siglo xix resultaron en una inundación de imágenes del mundo, plasmadas en medios nuevos y populares - prensa y libro ilustrados, estampa xilográfica y fotografía - El gusto por la aventura y el conocimiento de nuevas tierras y gentes discurrieron del viajero romántico al artista corresponsal

* Departamento de Historia del Arte. UNED. 
de la revista ilustrada, lo que introdujo variantes de interés en una vieja tradición de crónicas de viaje. En particular, los avances en prensa y comunicaciones permitieron al lector de revista seguir el periplo de un viajero, relatado en una serie de cartas al editor. Un temprano ejemplo de crónica periódica, aparecida en la Revue de Deux-Mondes de Paris, se debe a Teófilo Gautier, que viajó por nuestro país durante cinco meses en 1840. Hay ejemplos tardíos en crónicas sobre España de $H$. Castillon D'Aspet en L'lllustration, y A. Meylan en el Illustrirte Zeitung de Leipzig, aparecidas en 1873, al inicio de la última guerra carlista.

El medio periodístico, por otra parte, confería al reportaje de viajero una cierta distinción positivista. Cronistas ocasionales y corresponsales hicieron uso de un instrumento sociológico simple pero esencial, el cuaderno de notas y sketches. El inglés Richard Ford, autor del célebre Handbook for travellers (1845), lo llevaba consigo dondequiera que se desplazase. En España la gente miraba con desconfianza al visitante extranjero que exhibía lápiz y cuaderno en público, y su prevención no resultaba del todo injustificada . Nuestro país, usualmente excluido del Grand Tour del inglés ilustrado del siglo XVIII, todavía aparecia en el XIX como una tierra exótica aunque incómoda; visitarla resultaba una "empresa romántica y azarosa", en frase de Gautier. Un artículo publicado en 1881 en la revista Magazine of Art señalaba que "España es quizás de todos los países de la Europa civilizada el menos frecuentado por el turista británico... ese respetable vagabundo que adopta hábitos nómadas en el otoño de cada año... Viajar por España no es fácil ni cómodo; no hay coches ni trenes exprés, toda la comida está impregnada de ajo, y mosquitos molestos invaden las pensiones por la noche" ${ }^{2}$.

Pero el medio periodístico también exigía brevedad, lo que llevó al recurso del uso intenso de imágenes, que la renovación de la xilografía y el espectacular desarrollo de las publicaciones periódicas habian hecho posible. Las revistas gráficas extendieron entre una pujante clase media el gusto ilustrado por una España exótica. Estampas pintorescas, muy atractivas para los lectores, perfilaron una imagen romántica de nuestro país. La prensa popular inglesa y norteamericana configuró en ese contexto su visión de la mujer española del siglo XIX.

Los grabados de las revistas funcionaron como cesuras pictóricas de una narrativa visual que registró tres variantes estéticas: una primera variante de caracter enciclopédico - la mujer concebida como Tipo social—, a

Robertson, lan: Los Curiosos Impertinentes. Viajeros ingleses por España desde la accesión de Carlos III hasta 1855. Madrid, Serbal, CSIC, 1988, pág. 214.

GriffITHS, Arthur: "The Artist in Spain", en The Magazine of Art, vol. IV. (1881), págs. 26-30. 
través de un repertorio tipológico de viñetas enmarcado en el Positivismo que en los años treinta y cuarenta había pretendido una completa descripción de la Sociedad; una segunda variante, resultado de relatos y guias de viaje - la mujer concebida como tópico literario-, mediante imágenes que traducían la alta pintura de la época al medio gráfico, o que un ilustrador plasmaba directamente en la revista; y una tercera variante, estrictamente periodística - la mujer como documento histórico de época-, recogida por un artista corresponsal en forma de ilustración de una noticia.

Ejemplos de la primera variante son cinco estampas del 8 de diciembre de 1855 en la revista americana Ballou's Pictorial Drawing-Room Companion, bajo el título "Sketches in Spain" (figs. 1 y 2). Todas ellas denotan esa iconografía clasificatoria que en el siglo xIX introdujo la mentalidad del sociólogo en las corrientes estéticas; los mismos comentarios adjuntos a las ilustraciones apuntan ese énfasis en la formulación de tipos. Interesa observar, sin embargo, que estos sketches se ajustan al modelo de viñeta realista, donde marco y ambiente son necesarios para la completa descripción del individuo. Aqui ya ha ocurrido la transición de la viñeta abstracta a una viñeta de nuevo cuño, en la que el ambiente y la persona aparecen inseparables. Como había señalado Balzac, el héroe romántico independiente, desligado de la sociedad, había muerto.

Al describir el primer grabado, "Spanish Ladies", el Ballou's Companion habla de bellezas españolas, y del contraste entre peineta y mantilla típicas y cierta elegancia de moda parisina. Esa elegancia, comprensible en las mujeres de una ciudad grande como Madrid, suponía, según la revista, la pérdida "del garbo con que novelas y canciones habian inmortalizado a la mujer española». Es claro que la referencia a los modos de París facilitaba la fijación de una figura tipológica previa, la mujer parisina, que en el contexto de la metrópolis moderna del XIX representaba la esencia de una particular femineidad urbana, la mujer burguesa ${ }^{3}$.

Dos sketches, "Spanish Nurses", presentan a nodrizas con niños. En el siglo $x \mid x$, las labores de nodriza dieron lugar a una industria floreciente que facilitó la inserción de la mujer rural en la ciudad ". La mujer pintora, emergente en la época como otra figura de trabajo femenino semidoméstico, se apresuró a escenificarla en óleos como "Wet Nurse and Baby» de Berthe Morisot, ó "Nurse reading to a Little Girl» y "Nurse and

GARB. Tamar: Bodies of Modernity. Figure and Flesh in Fin-de-Siècle France. Londres, Thames and Hudson, 1998, pág. 87.

NOCHLIN, Linda: Women, Art, and Power and other Essays. Nueva York. Harper and Row, 1988, pág. 39 . 

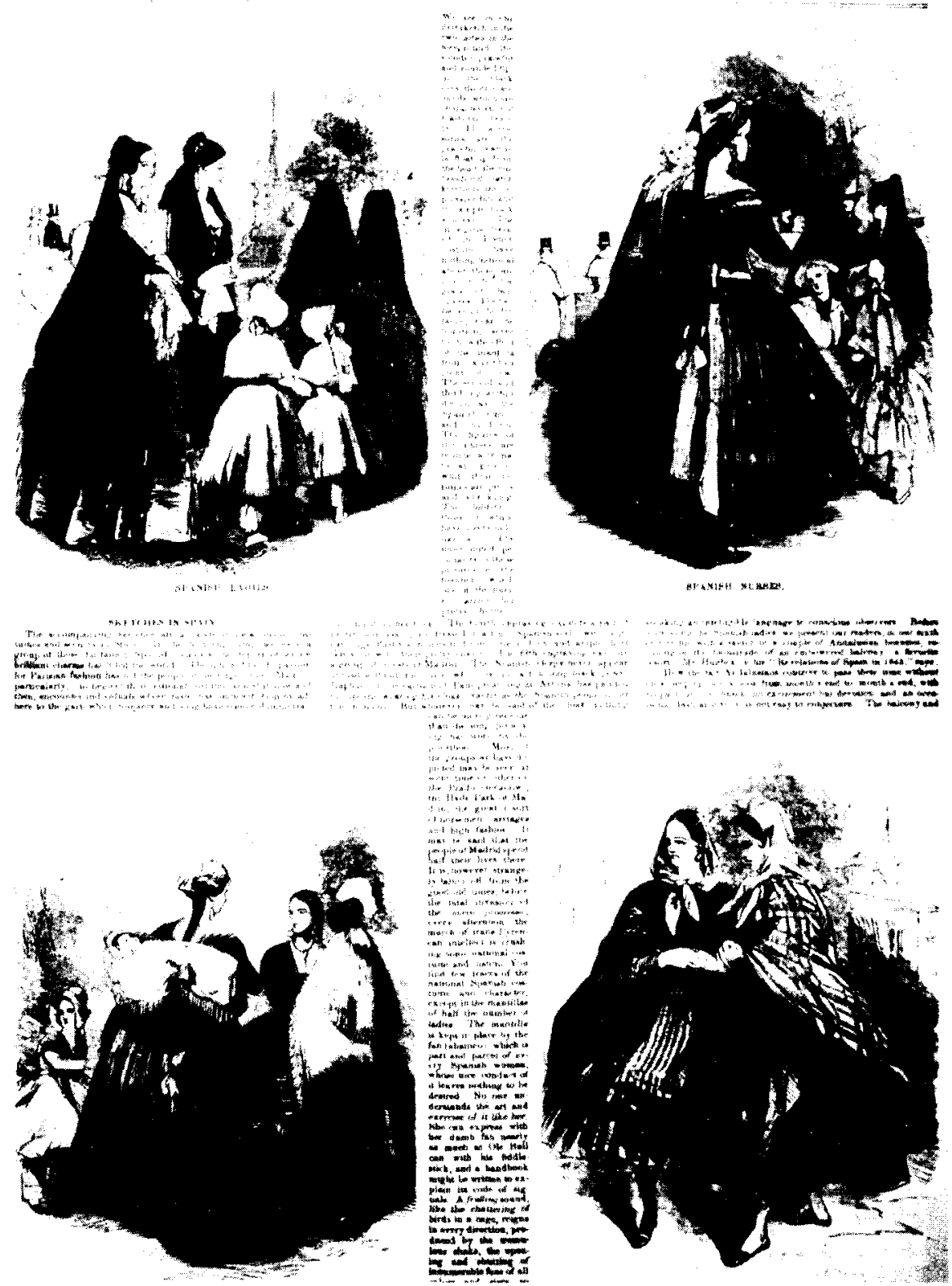

Fig.1. Spanish Ladies. - Spanish Nurses--. Manolas, Ballou's Pictorial Drawing-Room Companion, 1855. 


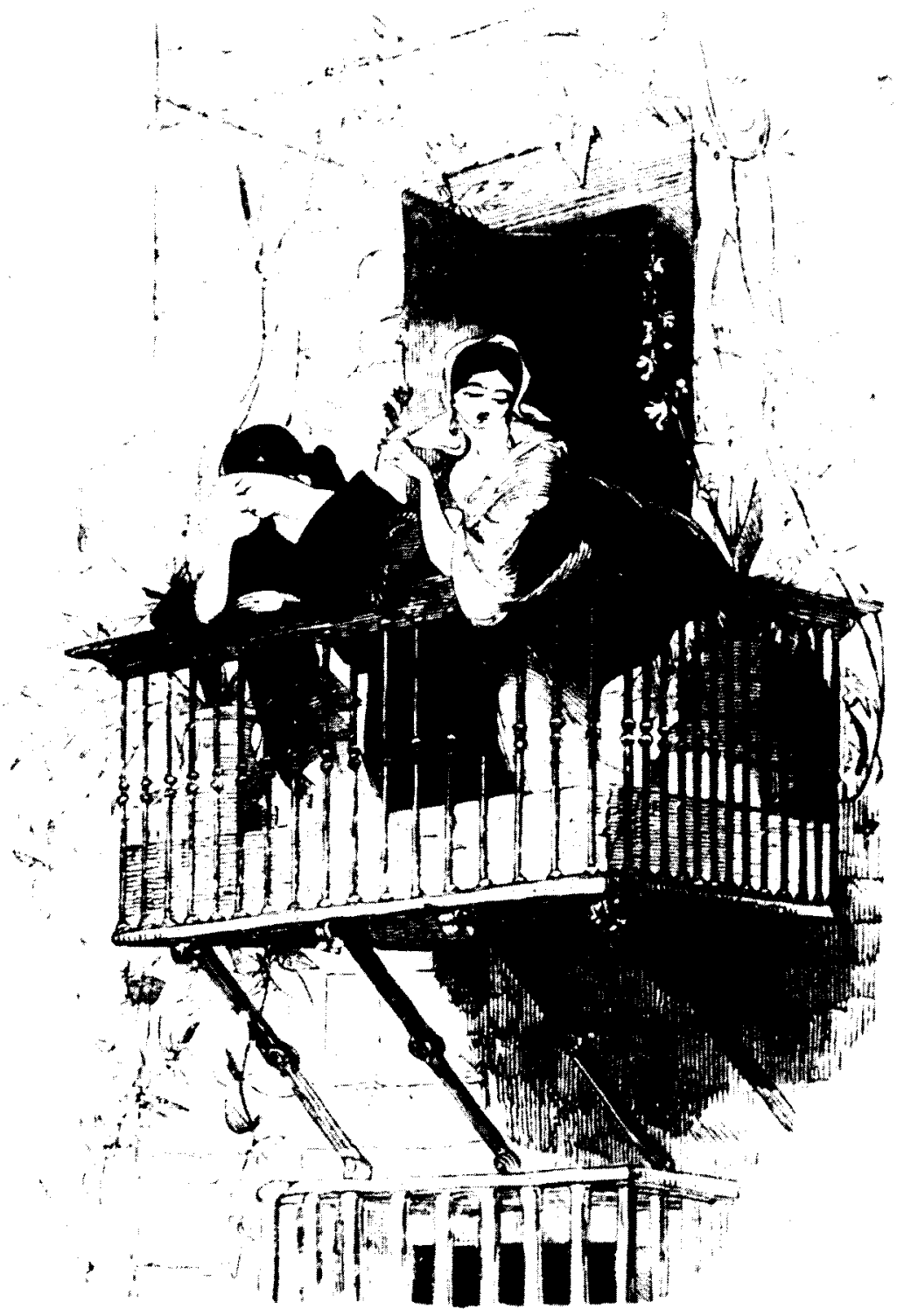

A BALCONY BCENE.

Fig. 2. A Balcony Scene, Ballou's Pictorial Drawing-Room Companion, 1855. 
Child" de Mary Cassat, y en acuarelas como "Liebe Nurse» de la pintora victoriana Lucette Barker. Quince años antes, en Olmedo, Gautier había visto a una nodriza pasiega, camino de un trabajo en Madrid, amamantando a un pequeño cachorro de perro para que no se le retirase la leche.

Mientras las viñetas anteriores obedecen a un discurso tipológico de mujer urbana, en «Manolas» (fig. 1) y «A Balcony Scene» (fig. 2) las connotaciones son fundamentalmente pueblerinas, de modos congelados en el tiempo. Las "Manolas" aparecen vestidas según una tradición de siglos: largos pendientes, pañuelo anudado en la barbilla, y amplia falda dejando ver los tobillos. Su iconografía sí obedece a ese "garbo inmortalizado en novelas y canciones"; por otra parte, el arrebato con el manto que muestran las figuras, junto al intento de captación del gesto momentáneo, recuerdan el motivo gráfico que Balzac señalaba como esencial en el arte del ilustrador periodístico: el vistazo rápido. En una viñeta del 2 de enero de 1858, «Street scene in Madrid, Spain» (fig. 3), el Ballou's Companion ofrecía una variante tipológica, la campesina venida a la ciudad a vender frutas del campo próximo.

"A Balcony Scene» se sitúa en un contexto típicamente andaluz, en el que un viajero podría suponer que miradores de celosía, herencia de la arquitectura árabe, permitian a las mujeres ver sin ser vistas. Aquí, sin embargo, aparecen dos andaluzas reclinadas sobre la balaustrada de un balcón. Interesa recordar un comentario de Griselda Pollock a un óleo de Mary Cassatt, "On the Balcony» (fig. 4): En el siglo XIX se calibraba la femineidad mediante una división social del espacio; un balcón abierto como el de la viñeta, desde el que se podía mirar y ser mirado, resultaba un espacio peligroso, una línea divisoria entre la respetabilidad de los interiores ocultos y el espacio no regulado de la calle pública. La postura de una mujer inclinada sobre un balcón se interpretaba como una provocación, y un indicativo de baja clase social ${ }^{5}$. Paradójicamente, la sociedad del XIx se nos aparece aquí muy próxima todavía a la que originó la celosía.

En el texto que acompaña a la viñeta, sin embargo, el Ballou's Pictorial Companion se aparta del argumento de la provocación. La revista sigue en su comentario al autor de Revelations of Spain in 1845, el arrogante viajero inglés Terence Mason Hughes, quién enfatizaba motivos de aburrimiento e ignorancia al explicar el femenino uso y abuso del balcón: "Es dificil entender que las bellas andaluzas puedan pasar mes tras mes sin ojear siquiera un libro, sin otro pasatiempo que ir a la iglesia ni otro goce

Pollock, Giselda: Mary Cassatt. Painter of Modern Women. Londres, Thames and Hudson, 1998, pág. 102. 


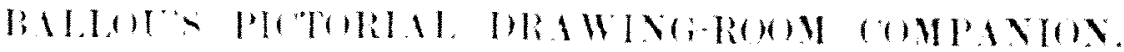

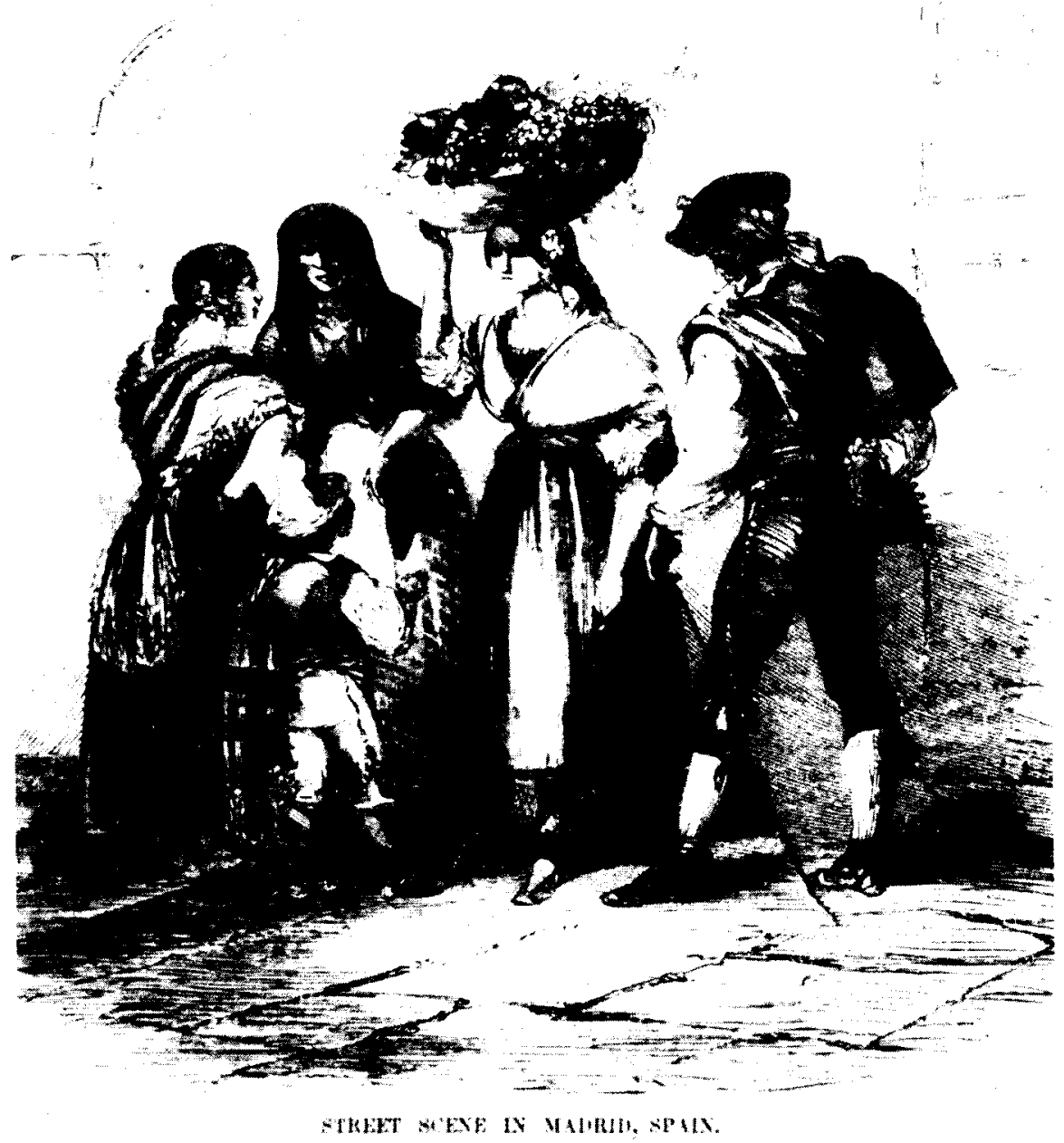

Fig. 3. Street Scene in Madrid, Spain. Ballou's Pictorial Drawing-Room Companion, 1858. 


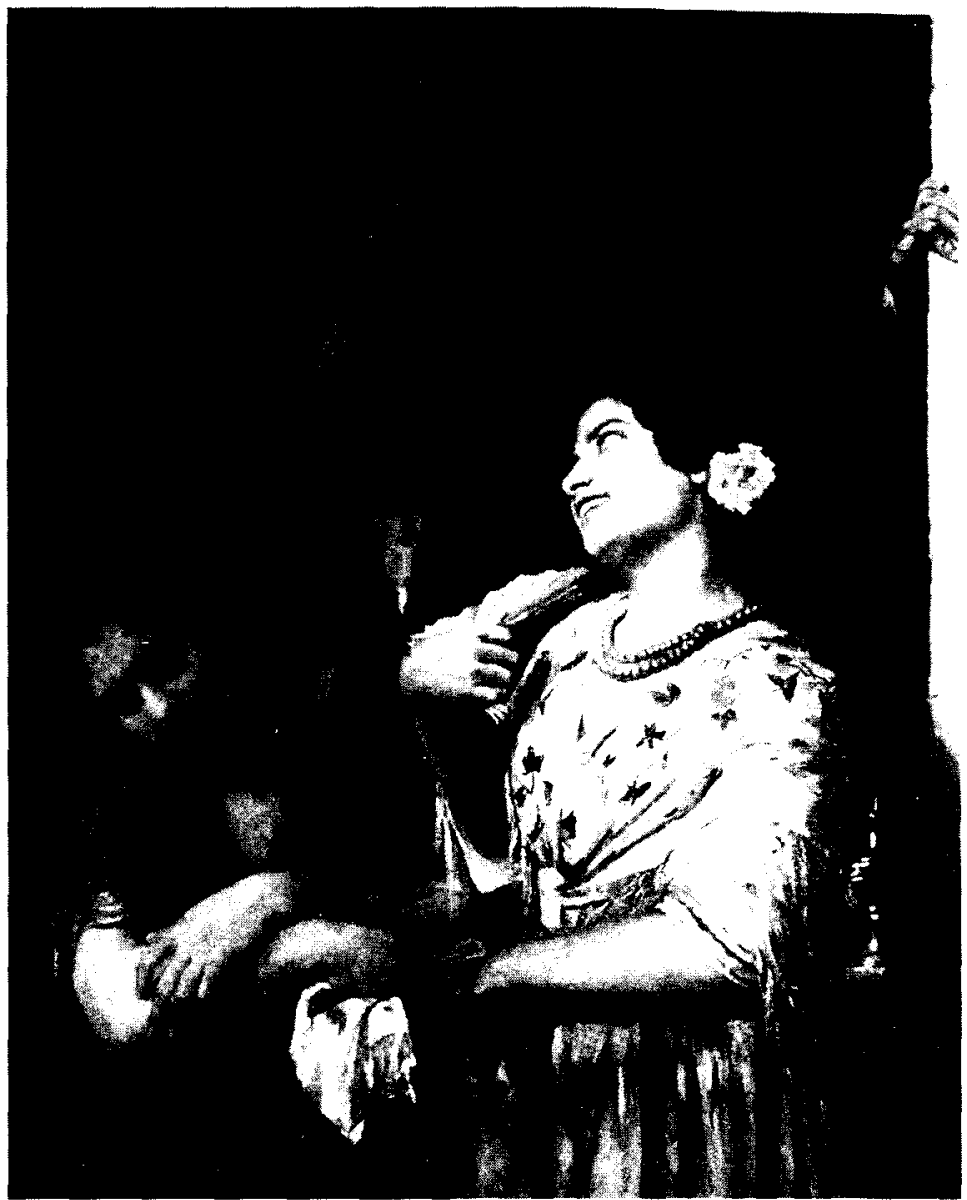

Fig. 4. On the Balcony. Mary Cassaft, 1873.

que la devoción y ocasionalmente un escarceo amoroso. Desde un balcón el pavimento de la calle termina aburriendo; raramente pasa un vehículo, y la vista del exterior es menos placentera que en otras ciudades a causa de los viejos toldos que cuelgan en las ventanas para proteger del tórrido sol. El amor es para las horas nocturnas, y aún las más pertinaces no pueden matar más de un par de horas al día en la iglesia. ¿Cómo llenar el inmenso vacio? ¿Cómo llenar los días sin otro libro que el Rosario de la Virgen y las Horas castellanas? Se usan las cuentas de los rosarios aún más que los libros de rezos... Cuando le pedí a mi patrona, la señora doña Isabel M. ${ }^{\text {a }}$, que me firmase un recibo por el alquiler de mi habita- 
ción, no supo hacerlo. Su hijo, un joven de veinte años, no era capaz de escribir sin falsilla».

"A Balcony Scene" es un boceto delicado, reproducido con una muy notable técnica xilográfica. El uso de acentuadas manchas negras contrasta con un sombreado de tonos blancos y líneas grisáceas que contribuyen a crear el volumen de las figuras. La animada vegetación que envuelve la escena hace recordar la delicada y elegante factura caligráfica de las xilografías japonesas.

Ejemplos de la segunda variante estética son las reproducciones de cuadros sobre mujeres españolas, sea en el entorno de la fiesta taurina, sea en el mundo del espectáculo, ó simplemente pintorescas con sus mantillas y abanicos; este es un claro rastro del tópico que visitantes franceses y británicos habían acuñado en relatos y guías de viaje. Fueron muchos los pintores del XIX que viajaron por España en busca de rasgos de exotismo femenino que llevar al lienzo. En su portada del 10 de octubre de 1868 "The Water Drinkers" (fig. 5), la revista norteamericana Harper's Weekly reprodujo un óleo del pintor victoriano John Phillip sobre un motivo recurrente en las zonas tórridas de España. En la imagen un aguador atiende a dos jóvenes que regresan de misa. Recursos poéticos y coloristas como la languidez de las miradas, los detalles del vestuario y, de alguna manera, la misma arquitectura de fondo en la escena, que tiene lugar cerca del Palacio de Carlos V en Granada, ayudan a crear esa imagen romántico-pintoresca de la mujer andaluza. Phillip, que visitó España en 1851, recogió retratos de guitarristas, bailaoras, campesinos y bandoleros, en numerosos cuadros que tuvieron mucho éxito. Fué el mismo Philip quién llevó a la madera su pintura, que el xilógrafo grabó con considerable detalle.

La estampa “Le Fripier espagnol» (fig. 6), publicada el 13 de septiembre de 1873 en el semanario The I/lustrated London News, traduce un óleo de Worms recogido en una fotografía realizada por los Estudios Goupil. La escena presenta un rayado acorde con la técnica de xilografía en línea blanca de tipo interpretativo. El grabador tuvo que trasladar el cuadro, traduciendo la imagen fotográfica de tonos a la estructura lineal característica del grabado al hilo. Las paredes recargadas de decoración pintoresca, en el interior de este local de un vendedor de ropa usada visitado por una dama, responden a un motivo iconográfico muy usual en el siglo $x \mid x$.

Por otra parte, aunque la presencia del abanico supone una reiterada representación de signos de identidad en la mujer española, la estampa también sugiere y elabora otros valores, más cercanos al tema de las relaciones sociales. El discurso esteticista de los años sesenta categorizaba 

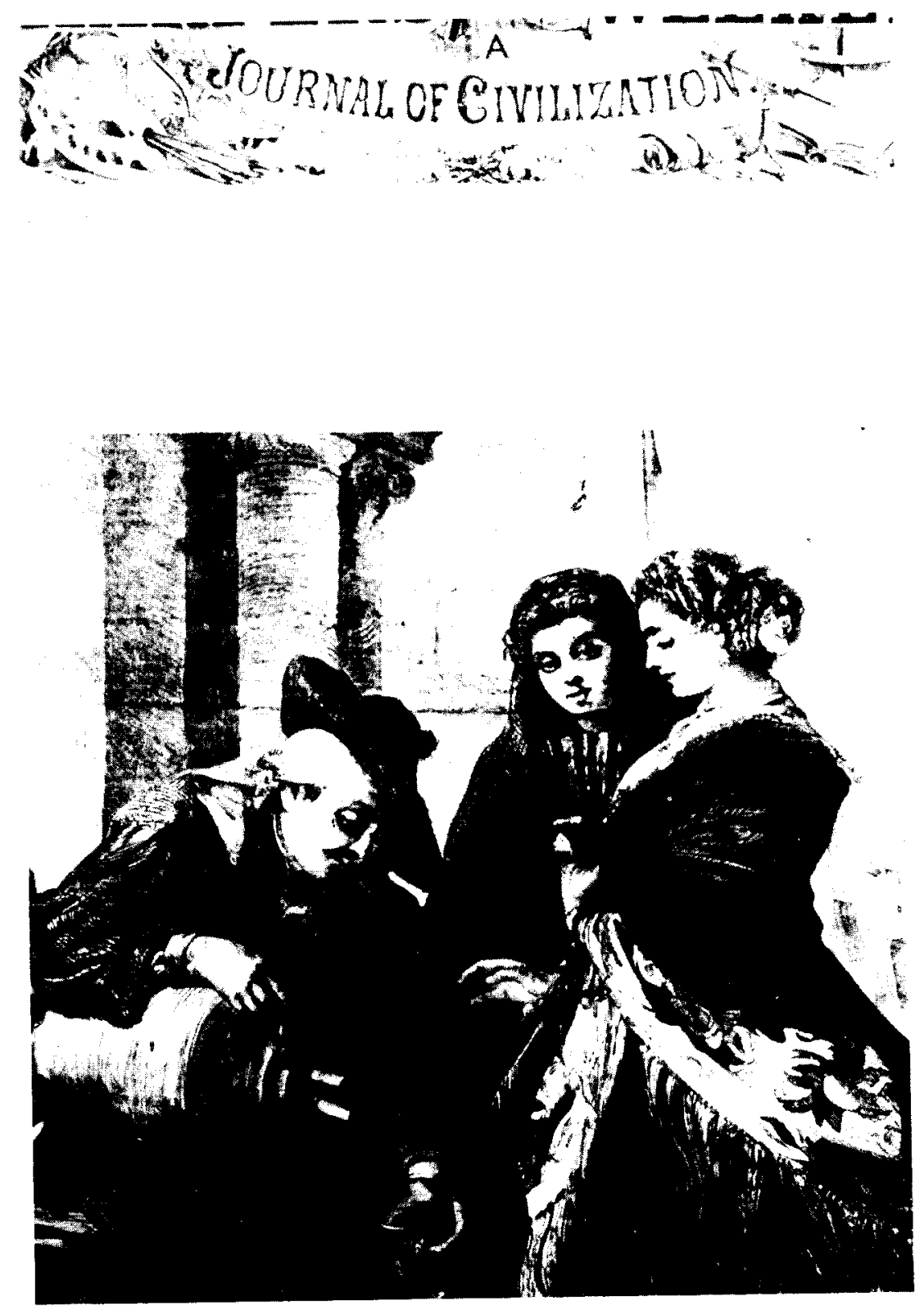

Fig.5. The Water Drinkers. John Phillip, Harper's Weekly, 1868. 


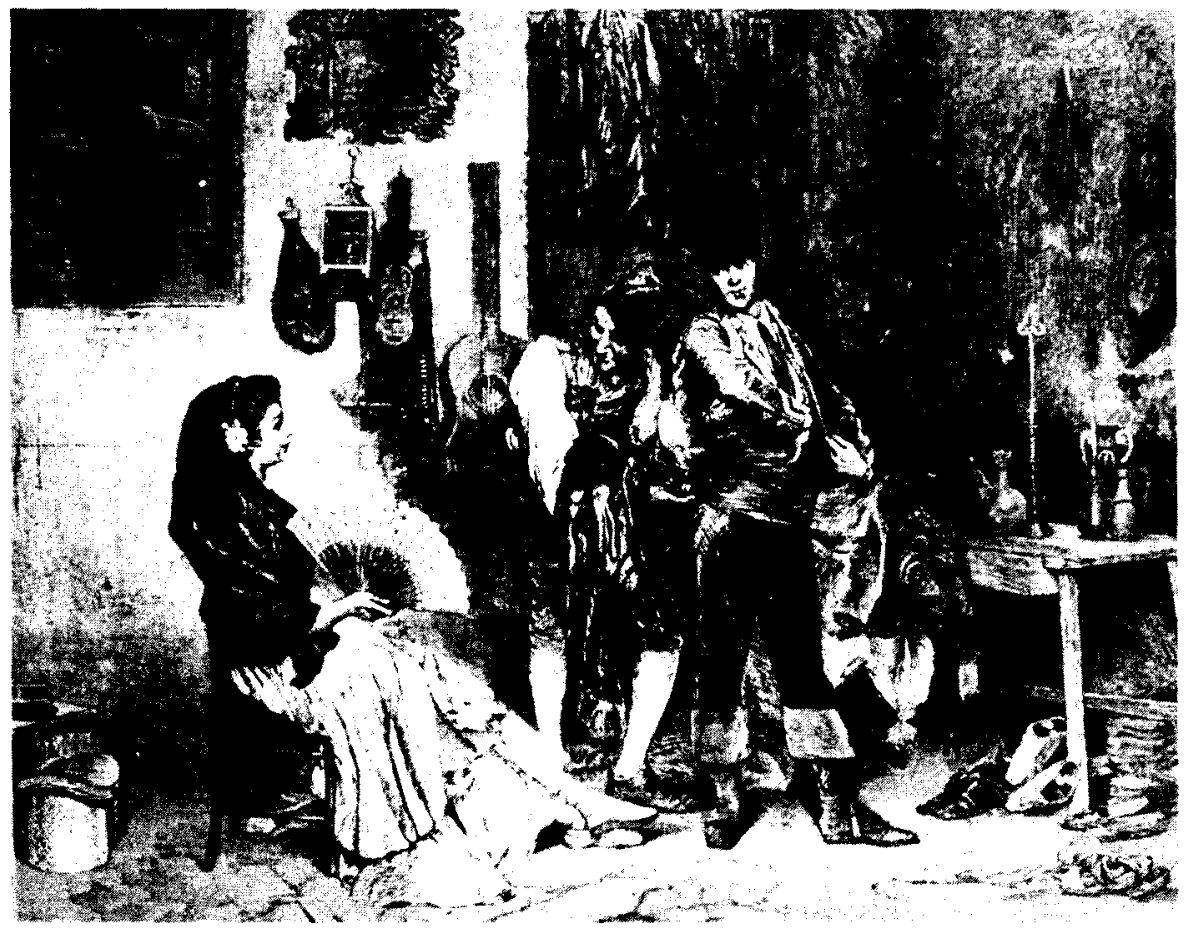

Fig. 6. Le Fripier espagnol. Worms, The Illustrated London News, 1873.

a la mujer como un icono de placer visual, ausente de valores morales ${ }^{6}$. Cualquier artificio de belleza femenina, en este caso el abanico, servía para enfatizar ese discurso y definir, al mismo tiempo, un rol femenino de narcisismo y «actuación», un tema muy querido por Baudelaire.

A fines de siglo ya existían múltiples técnicas para traducir una pintura a un medio gráfico. Esta portada del Harper's del 14 de junio de 1890 , sobre una bailaora española, «La Carmencita» (fig. 7), es probablemente una fotoxilografía, un procedimiento mixto frecuente en las revistas de la época, en el que sobresalieron particularmente los grabadores americanos. Una vez fotografiado el cuadro, se exponia la plancha de madera, sensibilizada a la luz, debajo de un negativo. El grabador trataba entonces de simular la tonalidad fotográfica en un medio tan diferente como las xi-

Cheray, Deborah: Painting Women. Victorian Women Artists. Londres, Routledge, 1993, pág. 88. 


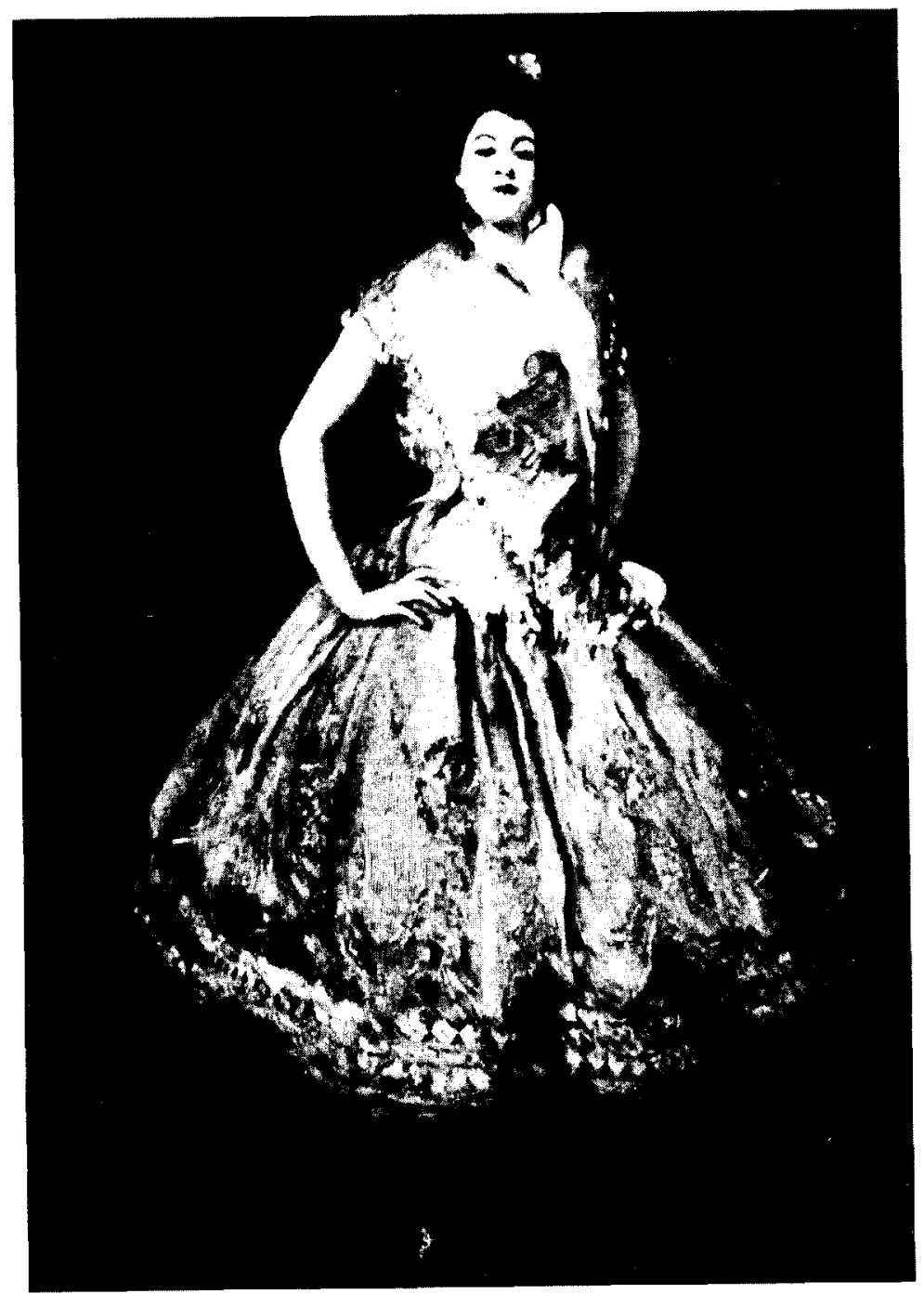

Fig. 7. La Carmencita. John Singer Sargent. Harper's Weekly, 1890. 
lografía. En la estampa se aprecian técnicas variadas, que van del rayado del vestido al punteado de rostro y brazos, un procedimiento utilizado para simular la apariencia del fotograbado de trama.

El autor del lienzo, el impresionista norteamericano John Singer Sargent, lo expuso en la Sociedad de Artistas Americanos de Nueva York. La gran acogida, según el Harper's, fué similar a la del "Jaleo" - una de las joyas del Museo Isabella Stewart Gardner de Boston-, que data de la visita del artista a España diez años antes. Iconográficamente, la "Carmencita", cuya fuente podría ser la "Lola de Valencia", pintada por Manet en 1862, muestra un estilo evocador de ese españolismo de literatura turística. Pero el cuadro de Sargent, como las viñetas sobre nodrizas mencionadas anteriormente, se nos aparece también como una representación del trabajo femenino de la época, ligado en este caso al arte y el entretenimiento, en conexión con supuestos pictóricos impresionistas. En una iconografía de la mujer trabajadora, sin embargo, el mundo del espectáculo se hallaba en el siglo XIX en una posición de ambigüedad. En la ideología de la Tercera República francesa, el epítome del trabajo como actividad productiva correspondía al mundo rural, y el esfuerzo físico de las bailarinas de Degas, con todas sus horas de ensayo, se consideraba fácil y espontáneo ?. En todo caso, la negación de cualquier penalidad a esa actividad, considerada como algo natural, descansaba en la noción misma de que la participación en un espectáculo artístico producía placer, un juicio relacionado con la categorización de la mujer como icono visual.

Para lectores sumergidos en los tópicos de la España pintoresca, el espectáculo más fascinante, sin duda, era la fiesta de los toros, "ese vestigio de la pasada barbarie que todavía tiene un extraño atractivo para aquellos que admiran la intrepidez y valor de esos hombres" ${ }^{8}$. El grabado «Preparing for the Bull-Fight» (fig. 8), publicado en la revista norteamericana Harper's Bazar el 8 de marzo de 1875, no tiene como soporte una pintura; se trata tan sólo de la ilustración que enriquece un texto. Siendo el Bazar una revista literaria, que integraba estampas con artículos o relatos, el artista debía poner más énfasis en la anécdota humana que en la fiesta en sí. Siguiendo el contenido del texto, en el que se juzgaba a las corridas de toros como "disgusting exhibitions", eligió ilustrarlo con un motivo secundario pero de mayor carga humana: los preparativos previos a la corrida, en los que la mujer conforta al torero y le ayuda a vestirse de luces. 


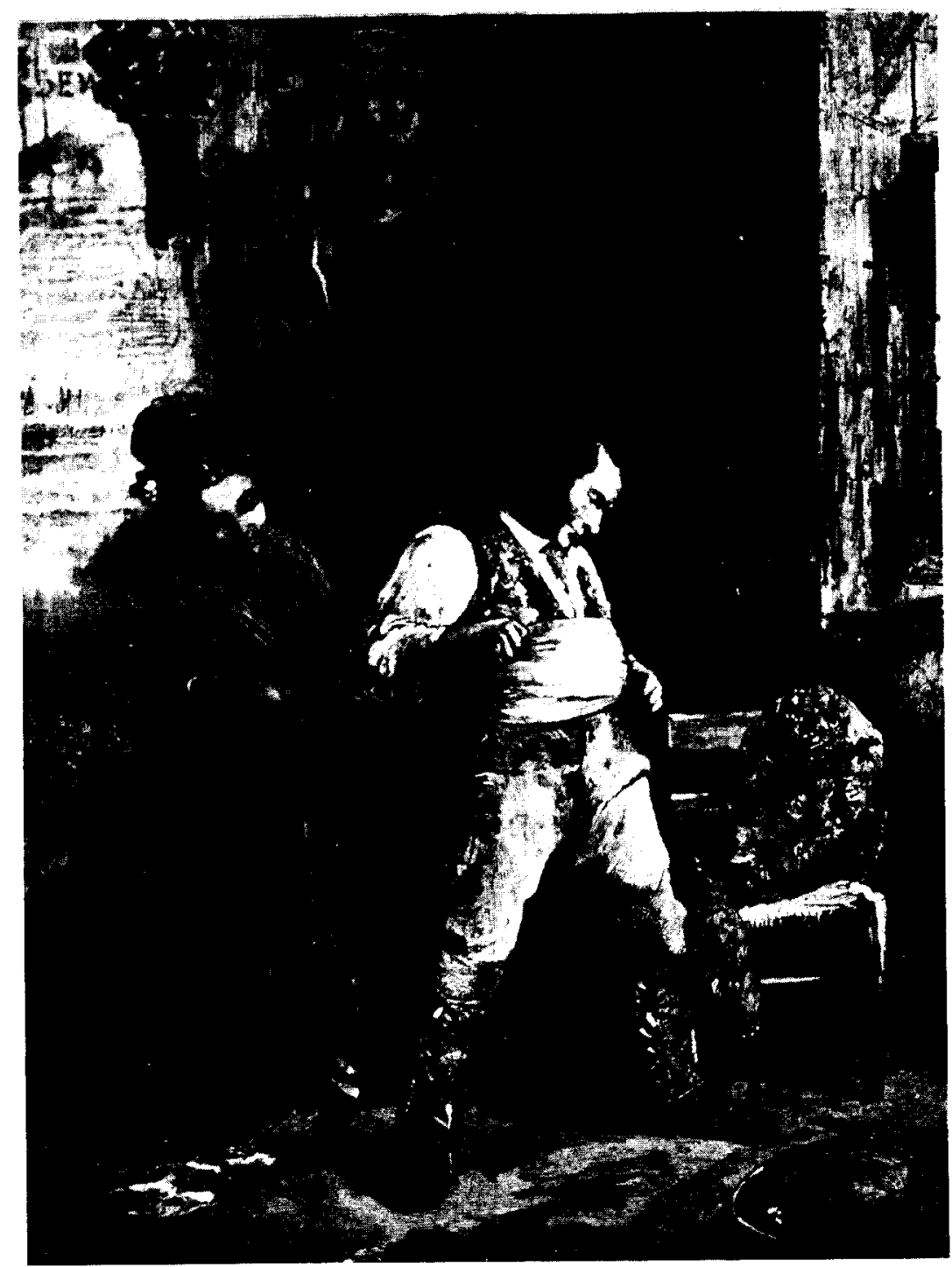

Fig. 8. Preparing for the Bull-Fight, Harper's Bazar, 1875. 
Una simple ojeada a la estampa permite deducir que, más allá de la imagen pintoresca, el tratamiento de esta escena de interior doméstico resulta en una plasmación de roles sociales que trasluce y despliega actitudes y figuras dominantes, que la ilustración misma se encarga de subrayar. La composición de la escena se organiza a través de contrastes tonales que confrontan a las dos figuras en un juego de luces: fuerte iluminación para el hombre y obscuridad para la mujer. En el contexto del siglo XIX, esa manifestación de la polaridad masculino-femenina debía entenderse en relación con la aparición de la sociedad industrial, que propugnaba la separación entre lo público y lo privado, entre el trabajo en tiendas, fábricas y oficinas y el hogar lejano, y conducía así a un ideal femenino de culto a lo doméstico.

En las bases de esta separación se pueden adivinar respuestas patriarcales y discursos de poder. La estampa del Harper's del 8 de enero de 1876, "Culprit reading a proscribed book» (fig. 9), es una representación iconográfica de relación de dominio por parte de una autoridad masculina, en este caso un cura, respecto de una joven que transgrede el "natural» orden femenino de auto-renuncia. Según el Harper's, la estampa «muestra a una joven dama española que ha sido sorprendida by one of the priesthood' en el acto de leer un libro prohibido. La seria naturaleza de la ofensa se puede colegir 'from the indignant expression of the angry father and the look of penitence and humiliation worn by the fair culprit'".

El apartamiento de la mujer de todo lo que significase cultura, como un propósito constante de la iglesia española, había encontrado eco tres años antes en el Harper's del 30 de agosto de 1873, que señalaba que el clero era el causante de la ignorancia del pueblo español y en especial del campesinado. Esa misma percepción de ignorancia y humillación en la mujer, se observa en una estampa del Illustrated London News del 10 de mayo de 1873, "The Archbishop of Granada denouncing the Republic" (fig. 10), que corresponde a la tercera variante, la periodistica, sobre imágenes de la mujer española en la ilustración de una noticia, partiendo de un dibujo tomado in situ. La estampa de la revista inglesa enfatiza la actitud humillada de las mujeres, todas de rodillas, en contraste con los hombres, que se mantienen de pié.

De muy distinto carácter es un grabado del lllustrated London News del 19 de abril de 1873, "Demonstration of women to demand release of prisoners" (fig. 11), que muestra a un grupo anónimo de mujeres en una reivindicación de carácter sociopolítico. El motivo del paraguas en la estampa, reproducido frecuentemente por Impresionistas como Manet o Renoir, provenía de los grabados japoneses de la escuela Ukiyoe, que había mostrado 


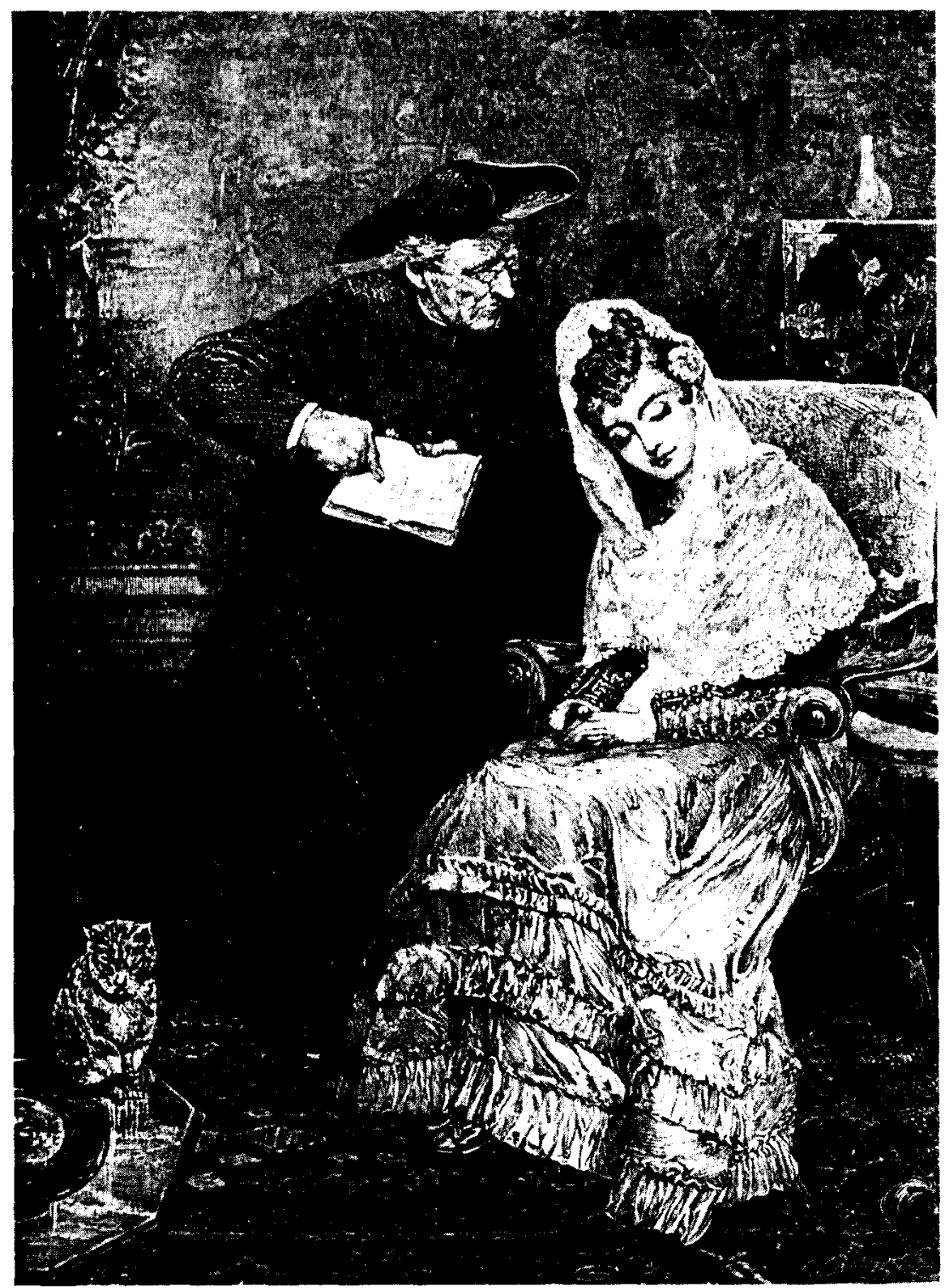

Fig. 9. Culprit Reading a Proscribed Book, Harper's Weekly, 1876. 


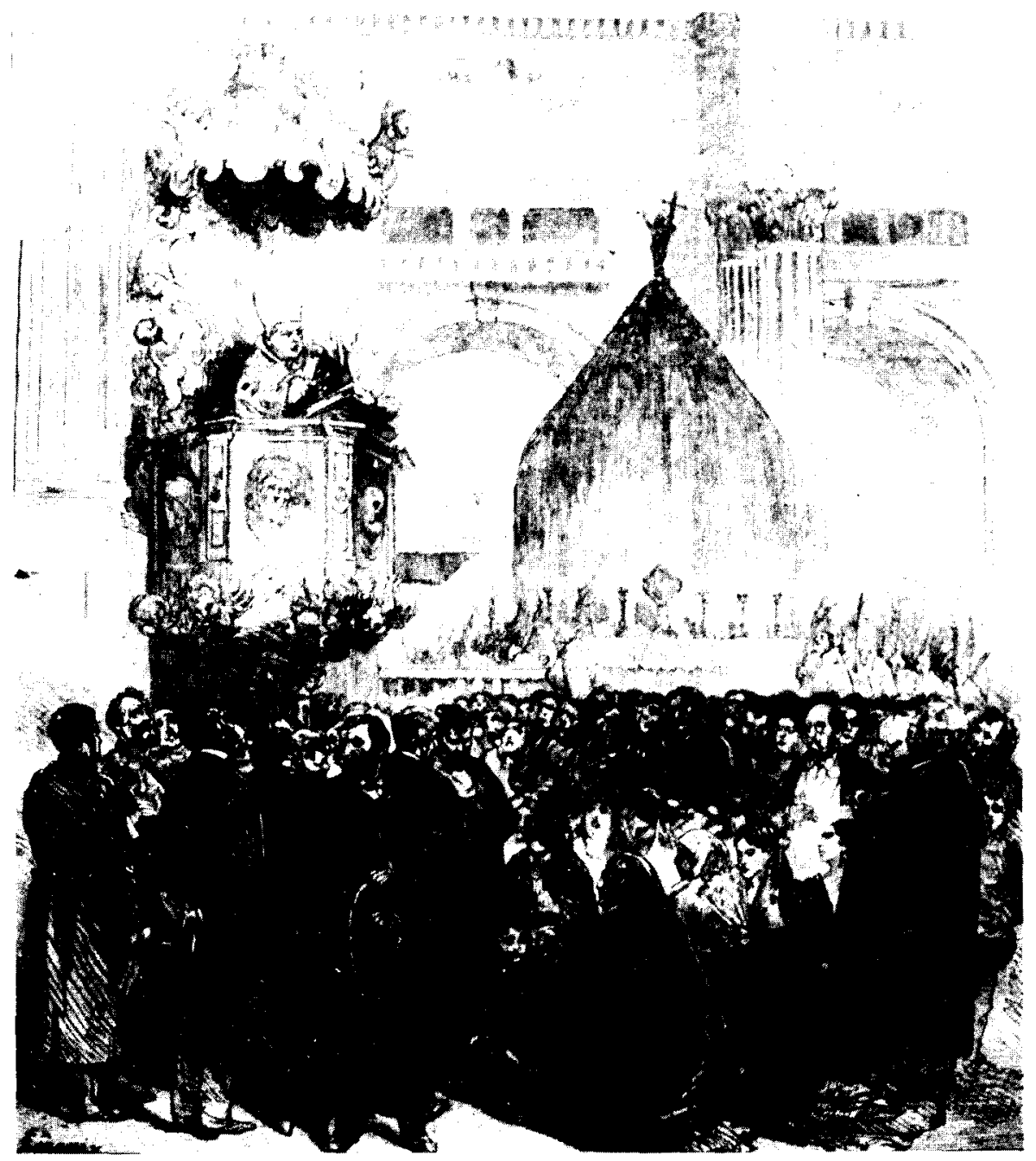

Fig. 10. The Archbishop of Granada Denouncing the Republic, The Illustrated London News, 1873. 


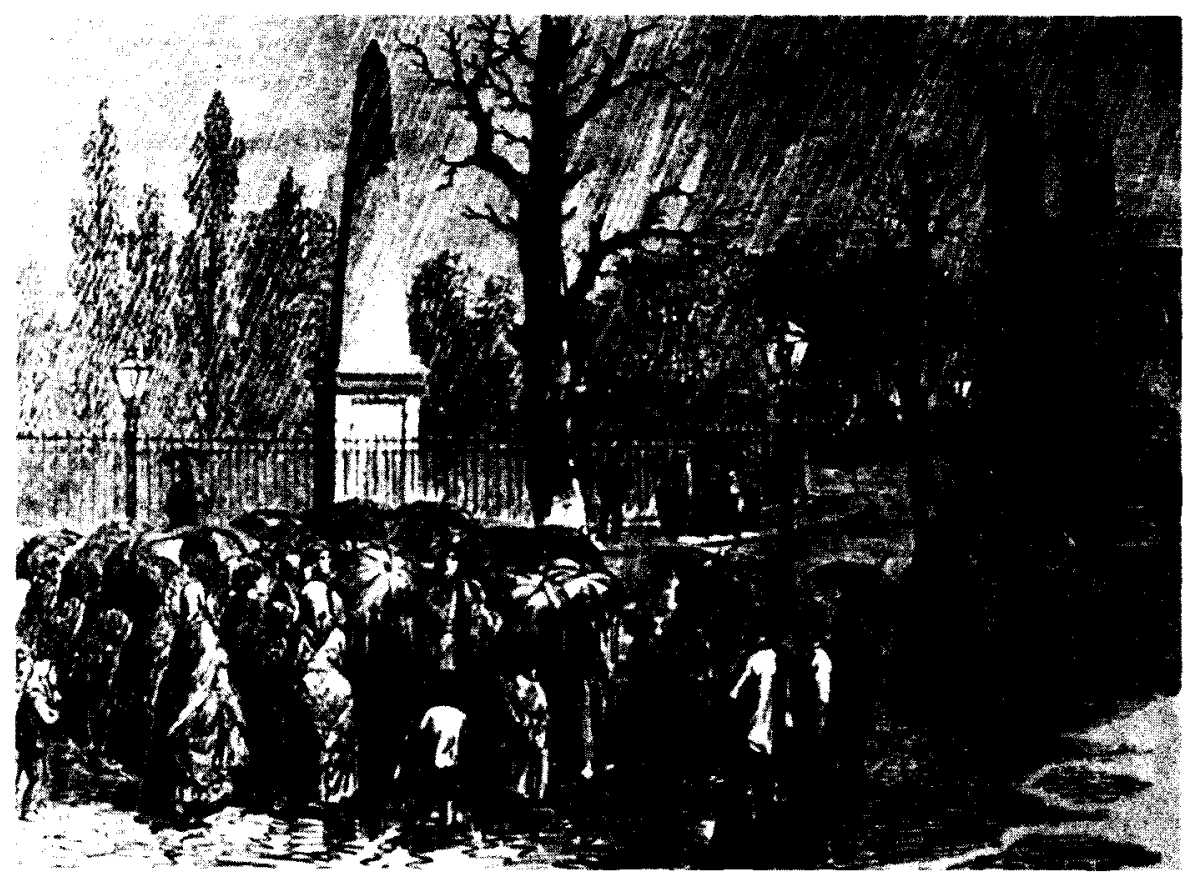

Fig. 11. Demonstration of Women to Demand Release of Prisoners, The Illustrated London News, 1873.

como incorporar fragmentos innovativos dentro de una composición compleja ${ }^{9}$. Dialécticamente opuesta es una estampa del Canadian Illustrated News del 24 de octubre de 1874, "Carlist prisoners at Vittoria" (fig. 12), que recoge la visita de las damas de un comité de beneficiencia a un grupo de prisioneros carlistas. La escena evoca el tema de la mujer del bandolero, que V. Schnetz había tratado en 1824 en su Femme de Brigand. En la escena hay también una sugerencia de flirteo, como en una pintura coetánea, "Joven ofreciendo azucarillo al torero", que expuso Mary Cassatt en Nueva York en 1874; tanto en la estampa como en la pintura el artista recurre a la presencia de la mujer para crear una tensión en la composición.

De toda esta narrativa visual de la prensa anglosajona, la mujer española emerge, fundamentalmente, como parte integral de un catálogo de lo pintoresco que va más allá de la simple descripción de una variedad de monumentos históricos y costumbres locales.

9 Needham, Gerald: 19th Century Realist Art. Nueva York, Harper and Row, 1988, pág. 49. 


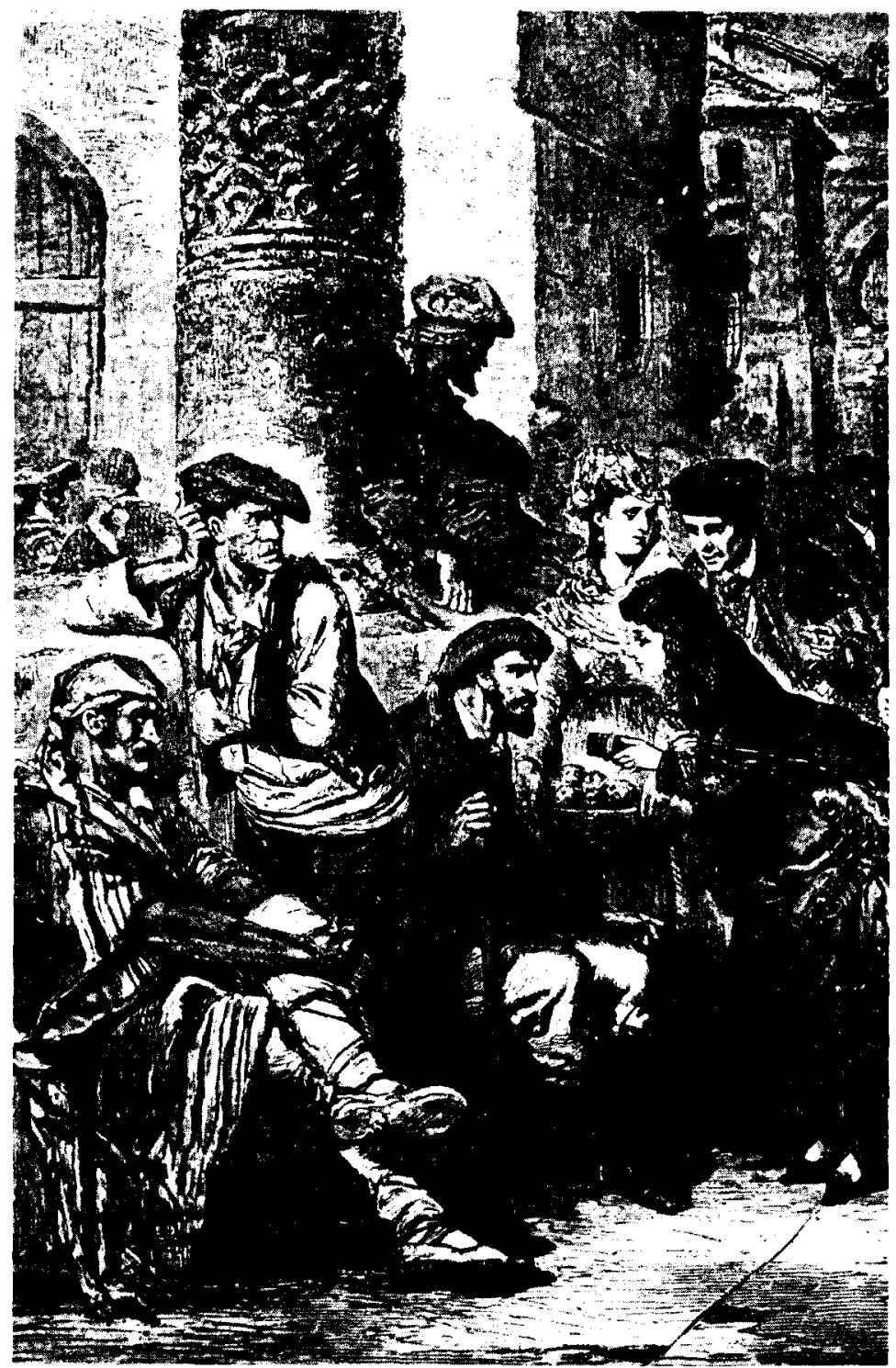

Fig. 12. Carlist Prisoners at Vittoria, Canadian Illustrated News, 1874. 
El consumismo retórico del viajero ilustrado incluyó a las españolas en una generalizada invocación al pictorialismo, concepto empleado desde el siglo XVIII para señalar lo que en páginas de revistas y libros ilustrados se asemejaba a un cuadro. Pero el interés de la prensa angloamericana de la época en la construcción de esa imagen no quedó limitado por el pintoresquismo. Se quería enfatizar, asimismo, que en un pais católico como España la religión era un factor determinante en la formación de una domesticidad femenina desfasada, un leit-motiv religioso que las ilustraciones y los comentarios adjuntos exhibían, ya en los albores de la modernidad, ante las influyentes clases medias de Gran Bretaña y los Estados Unidos ${ }^{10}$.

10 Como se ha reconocido, el «arte impreso fue un instrumento cultural básico para la burguesía y a ella se dirigia especialmente". GARCia MELERO, José E.: Arte Español de la llustración $y$ del siglo xix. En torno a la imagen del pasado. Madrid, Ediciones Encuentro, 1998, pág. 204. 